\title{
NEWS
}

\section{Brazil mulls major climate action}

\author{
If adopted, the move would put the country ahead of other developing nations on emissions curbs.
}

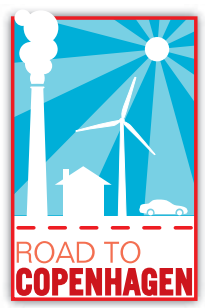

Building on an existing pledge to slash deforestation rates in the Amazon, Brazil is considering a commitment to substantially reduce cumulative greenhouse-gas emissions over the next decade.

Details were under discussion as Nature went to press, but such a commitment would represent the most significant step yet by a developing country going into December's United Nations climate summit in Copenhagen. It could also help to bridge the gap between rich and poor countries, while increasing pressure on industrialized nations to boost their commitments.

"What's really important is that Brazil has seen that it can lead by example," says Steve Schwartzman, who heads tropical-forest policy for the Environmental Defense Fund in Washington DC. "This is a major step. It's tantamount to taking a national cap."

Under the current global-warming framework, only industrialized nations would be required to 'cap' and then reduce their greenhouse-gas emissions. Developing countries are focusing on policies to reduce emissions growth and set up low-carbon development.

Although Brazil is not discussing a binding emissions cap, scientists and government officials have been updating the nation's greenhouse-gas inventories and quantifying potential reductions. Preliminary results from one analysis suggest that the nation could cut its projected emissions in 2020 by $35 \%$, which would equate to roughly $8 \%$ below 2007 levels. The government is also discussing even deeper cuts, all contingent on international aid.

"We are just estimating the magnitude of reductions that we can obtain by 2020," says Carlos Nobre, a climate scientist at Brazil's National Institute for Space Research in São José dos Campos. "The next step is to put a dollar figure to each of those things, and then one has to discuss how to get financing."

Working with the scientist network RedeClima, Nobre recently calculated for Brazil's environment ministry that the country could reduce its annual emissions by the equivalent of nearly 1 billion tonnes of carbon dioxide (see graphic) by 2020. Nearly two-thirds of that would come from an existing commitment to an $80 \%$ reduction in deforestation - now responsible for more than half of Brazil's total emissions - by 2020. But Rede-Clima estimates that another 320 million tonnes could come from the energy and agriculture sectors, as well as reforestation efforts.

"If we get assistance and we develop good policies here, we might get to 2020 with a maximum $40 \%$ reduction," Nobre says, and that would cost several billion dollars or more.

Marina Silva, an environmental advocate who resigned as Brazil's environment minister last year amid internal opposition to her policies, has been using her new post in the Senate to push for a comprehensive national target in Copenhagen. Speaking through an interpreter in Washington DC last week, she said

\section{BRAZIL'S POSSIBLE EMISSIONS CUTS}

Proposals under discussion by the Brazilian government would dramatically reduce the country's greenhouse-gas emissions and shift the sectors from which they come.

Projected emissions in 2020, in a business-as-usual scenario: 2.7 billion tonnes of carbon dioxide equivalent

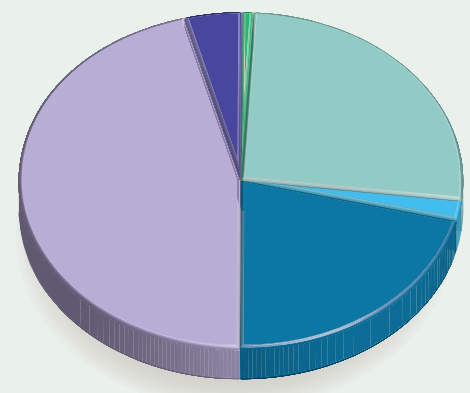

Projected emissions in 2020, with mitigation: 1.75 billion tonnes of carbon dioxide equivalent

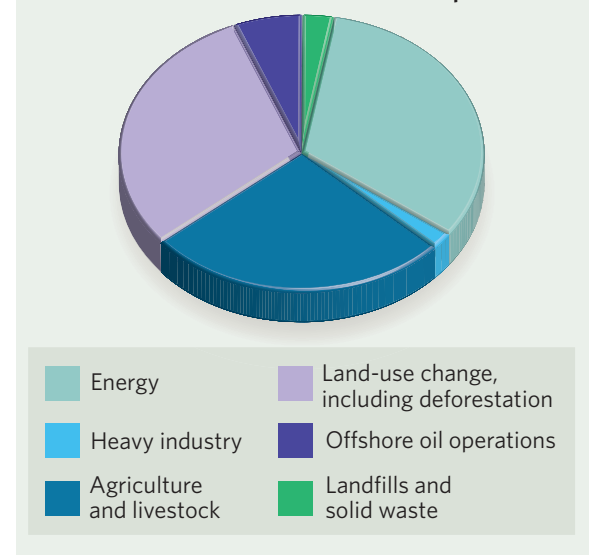

the principle of "common but differentiated responsibilities" might require wealthy nations to take the lead but does not excuse developing countries from taking action.

"It cannot be something that the developing countries hide behind in order to avoid making reductions," says Silva, who is expected to run as the Green Party candidate for president next year. "Our planet does not take into account where the emissions are coming from."

The government is also rethinking its position on the role of forest carbon in a future climate treaty. To date, the country has taken a lone stance in demanding that wealthy countries should not be able to offset their greenhousegas emissions by funding forest conservation in the tropics. The fear is that offsets would allow industrialized countries to delay action at home, but observers say that position may soften.

Brazil created the Amazon Fund last year as an alternative mechanism that would allow donor countries to help pay for the country's 용 ongoing programme to curb deforestation (see Nature 460, 936-937; 2009). Norway has pledged US $\$ 1$ billion up to 2015, assuming Brazil continues to make progress.

But President Luiz Inácio Lula da Silva appointed a task force to study the issue after nine governors representing Amazon states urged him in June to reconsider Brazil's policy on carbon markets, which they said represent "a golden opportunity" for sustainable development and forest conservation. That panel has proposed allowing nations to offset up to $10 \%$ of their commitment by purchasing carbon credits for avoided deforestation.

Schwartzman credits Silva with initiating change within the federal government. "Not very long ago, the official Brazilian position was that they did not want any discussion of deforestation in the international negotiations," he says. "It was at her urging that the Brazilian government reopened that policy and came to a different conclusion."

Officials with the environment ministry could not be reached for comment. As Nature went to press, Lula had scheduled a 3 November cabinet meeting to discuss the issue. It was unclear whether a formal position would be announced this week in Barcelona, where climate negotiators are meeting for the last round of formal talks before Copenhagen.

Jeff Tollefson

See also www.nature.com/roadtocopenhagen 